\title{
THE BULGARIAN DARETZ DIALECT FROM THE EASTERN RHODOPES- PHONETIC FEATURES
}

\author{
Iv. Iliev* \\ Plovdiv University, Kardzhali Campus, Kardzhali, Bulgaria
}

\begin{abstract}
This article presents the main phonetic characteristic features of the extinct Bulgarian dialect spoken in the village of Daretz till 1957. Daretz was the only Bulgarian village in the Kardzhali region, and it was surrounded by a Turkish population on all sides. Now it is at the bottom of the artificial dam called Studen kladenetz (Cold well). The village was inhabited by Christian Bulgarians, and its dialect was a mixture of the Bulgarian dialects spoken in Thrace and the Rhodopes.
\end{abstract}

Key words: Bulgarian language, Bulgarian dialects, Rhodopean dialects.

\section{INTRODUCTION}

The town of Kardzhali and the region around it became part of Bulgaria in 1912, during the Balkan War. Up to that time, they had been inhabited only by a Turkish-speaking population. Afterwards, Bulgarians, mostly from Western Thrace, came to the administrative center - Kardzhali. However, the villages extending to Chernoochene in the north, to Momchilgrad in the south, westwards to Dzhebel; and to Krumovgrad in the east, remained purely Turkish. The only Bulgarian village inhabited by Christian Bulgarians between Kardzhali and Krumovgrad was the unique village of Daretz (now beneath the waters of the Studen kladenetz dam). Its dialect, especially on a phonetic level, is the object of research in this article. The closest villages where the Bulgarian language was spoken are the villages around Haskovo to the north, the Pomak villages south of Momchilgrad and west of Dzhebel, as well as the villages of Bulgarian fugitives from Asia Minor and from Western and Eastern Thrace. About the dialectal situation in the Eastern Rhodopes, one can see Iliev (1).

Initially, the village of Daretz was inhabited by Yuruks. They gave the village its first name Yuruk (later, Yuglyuk). The name Daretz was given in 1934 (2). It is not known when the

${ }^{*}$ Correspondence to: Ivan G. Iliev, Plovdiv University, Kardzhali Campus - Kardzhali, Bulgaria,ivan_iliev20002000@yahoo.com first Bulgarians came to this place but, in 1844, there was a church at the village (3). According to Mihaylova (4), part of the inhabitants of Daretz came from the village of Dobrich, near Haskovo; another group came from the village of Sheytan, in the Smolyan region - maybe this is the present-day village of Kosovo (5); and the third one came from the village of Sachanli, near Komotini (now in Greece). This predetermines the mixed character of the dialect under research. The phonetic description of the Daretz dialect has been made on the basis of the only existing written materials, collected by M. Mihaylova, before the village was deserted and flooded by the artificial lake in 1957. These materials which present a description of everyday life and the customs of the Bulgarians who lived in Daretz - were not collected by a professional linguist, and they have not been transcribed in the appropriate way (even the accents were not written down). However, since we don't have any other materials preserved concerning the Daretz dialect, we will have to do with them (M. Mihaylova probably made some mistakes although, in many instances, she is consistent in showing the definite characteristic features). The only change that I made, citing the examples from Mihaylova, is the replacement of the letters $я, \wp, b$ by the appropriate dialectological signs, where I could safely guess where the position of the accent was. In the same way, some wrongly written voiced consonants have been replaced by voiceless 
ones. So far, the only works where the Daretz dialect has been mentioned are an article by Mitrinov (6) on the use of the interrogative pronoun кина̀ 'what' in this dialect, and also an article by Iliev (7), where it was stated that the Daretz dialect should be researched in the future.

\section{MAIN PART - THE PHONETIC FEATURES OF THE DARETZ DIALECT}

A. Development of the Old Bulgarian (C), -, $\mathbf{b}, \mathbf{b}, \mathbf{3}$

Unlike the Central Rhodopean dialect, in the Daretz dialect the development of the abovementioned Old Bulgarian vowels is the same as in the Thracian dialects or in the Rhodopean Zlatograd dialect.

(C) $\rightarrow b$ : $\kappa^{3}$ umama 'the house', $\kappa^{3}$ umume 'the houses', $n^{3} m$ ' '(one) time', $\mathcal{M}^{3} u \kappa u$ 'men', pъките 'the arms';

ъ $\rightarrow$ mainly $b: \partial^{3} u$ 'rain', $c^{3} H$ 'dream', etc., but: длѐга 'long (feminine singular)', длѐги 'long' (plural);

$\mathrm{b} \rightarrow$ b/e (in some cases the letter $e$ maybe

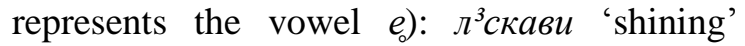
(plural), мъгла 'mist', but: тѐнку 'thin' (neuter singular), стемни са 'it became dark', дѐн 'day', учѐл 'who has gone';

$\mathrm{t}$ ' $\rightarrow$ el'a (rarely): дѐcem 'ten', тѐшкy 'heavy(-ily)', врѐме 'time', 'weather', светѐна ода 'holy water', светѐцът 'the saint' (but also cв'amu 'holy'), в'àзмy $\partial а$ cu везе 'to embroider a piece of embroidery', пугл'а̀ва 'he (or she) takes a look';

$\mathrm{t}^{\prime} \rightarrow\left({ }^{*} a\right) / \mathrm{b}$ (mainly in the forms of reflexive pronouns): сгр'àum ca '(you) get warm', ca

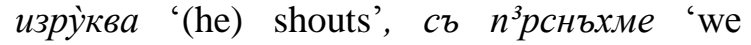
dispersed', $\varkappa^{3} \partial н и$ 'thirsty' (plural).

The vowel $э \rightarrow$ ' $a$ in all positions (with rare exceptions): гул'а̀мет 'the big one (masculine singular)' - гул'àsu 'the big ones' (plural); p'àката 'the river' - p'àките 'the rivers'; p'àчката 'the small river'; н'àmmy '(some)thing'; л'àк 'a medicine', л'àбъm 'the bread', сгр'àum ca 'you (sg.) get warm'; тр'а̀ви 'herbs'; вр'àmemy 'the time', 'the weather' (but also врѐме); умр'а̀лите 'the dead'; чув'а̀шки 'human'; m'àффни 'their'; в'а̀шки 'eyebrows'; м'àceu 'month'; дубр'à 'well'; dв'àme 'both (women)'; d'àme 'a child', d'amumme 'a big child' (but: дuu̧à 'children', duùama 'the children' - here, maybe because of the unaccented position). Replacement $э \rightarrow e$ under stress is attested in недѐле 'sunday', бѐлу вйну 'white wine' (by the way, all shown forms may contain $\hat{e}$, written as $e$ ); one can see $a$ in на cpade нйвата 'in the middle of the field', as well as in all forms of 'whole': ияал дѐн 'a whole day', има̀ла гудѝна 'a whole year', ияа̀лата 'the whole (feminine)', ияа̀тmy сѐлy 'the whole village', uа̀лет стан 'the whole loom'.

\section{B. Reduction of unstressed vowels}

More-frequent are the cases of reduction of the vowels $o$ and $e$ :

$o \rightarrow$ y: утк'иваме 'we tear', гул'а̀ми 'big (ones)', вр'àmemy 'the time', 'the weather', cѐлy 'a village', дурдѐmy 'until', ny 'on', 'along';

$e \rightarrow u$ : дuu̧à 'children', duu̧àma 'the children', идйн 'one', прис 'during', 'through', търчѝми 'we run', прика̀рат 'they spend (the night)', 'they endure', ста̀ним 'we get up', мо̀жиш да ка̀жиш 'you (sg.) can say'.

Less frequent are the following cases of reduction:

$e \rightarrow$ s: слът пладнйна 'in the afternoon', оेсъм 'eight';

$a \rightarrow$ b: шъка̀ 'a joke', пърлиेва пипѐрка 'a hot pepper', къскандйсвам 'I envy', but: касканма̀к 'envy' (as a noun).

\section{Changes of stressed vowels}

The following cases can be seen.

$\grave{o} \rightarrow \grave{y}:$ ym Г⿳亠丷厂 $n y \partial e$ 'from God', Гỳcnymue 'Dear God (diminutive)', nỳdaмe 'we go' (a very common phonetic change in the Rhodopean dialects), $n \dot{y} \partial a$ '(he) goes', $\partial y x \dot{y} \partial a$ '(he) comes', нaxỳdame 'we find', and, which is very interesting, umyे/cmy/umy 'what', umỳmy 'whatever'. It may be a coincidence or not, but the use of the forms umyे и common in the vernacular of the town of Zlatograd, too, where the Zlatograd $b$-dialect is spoken (8);

$\grave{e} \rightarrow \grave{u}$ : this change, typical for many Eastern Rhodopean dialects, is present in the dialect under research, too: ynpùm 'at the front', $H^{3} \breve{u}$ напрѝm 'first (of all)';

$\grave{a} \rightarrow^{3}$ : the change is seen in $\kappa^{3} \kappa$ 'how', $\kappa^{3} \kappa m o$ 'however', and, in a clear consecutiveness, in the superlative degree particle $H^{3} \breve{u}: H^{3} \breve{u}$-напрйm 'first (of all)', etc.;

The change $o \rightarrow^{3}$ is observed in $H^{3} u$ 'night', and the change $\grave{a} \rightarrow \grave{e}$ is consecutively seen in делѐче 'far away', делѐкy 'far away', nòделѐку 'the farthest'.

\section{The change ' $a \rightarrow e$}

The change ' $a \rightarrow e$ is attested in the following word: едѐ '(he) eats', едѐм 'we eat', наедѐм 'we eat enough', пѐdе 'a span', недѐле 'Sunday', mèc грòme 'six pennies', зѐ e '(he) took her', нимой е $\phi^{3}$ рле 'don't throw her', ета̀к 'rebel's helper', коेнет 'the horse', огенет 'the fire', изгуретm 'they will burn', 
but: б'àme/бème '(it) was', m'àве/mèве 'these'.

\section{E. Labialization and delabialization}

These changes are rarer but they could be illustrated by the examples кол'уेвy 'wheat, boiled for commemoration' - for the first one,

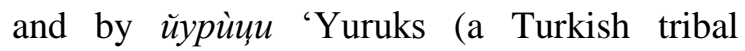
name)' for the second one.

F. Elision of vowels: $n^{3} u u a$ 'a bowl', сирма̀шка жена 'a poor woman', ица̀ma 'the eggs', ùàrme 'do come' (plural).

\section{G. Changes of consonants}

The change $\boldsymbol{c} \rightarrow \boldsymbol{\mu}$ : $у m \kappa^{3} u a$ '(he) tore', утк ивваме 'we tear', утк $\kappa^{3}$ иам 'you (sg.) tear', пуиува '(he) swears at someone'. The change can be seen in different Eastern Rhodopean dialects, for instance, in the village of Pripek, in the Dzhebel region (9).

The change $\boldsymbol{\varphi} \rightarrow \boldsymbol{u}$ : исnùuave 'we bake', ynùuam 'they bake', цъврвйло 'a kind of grass', иърнйлуту 'blacking', царнѝца 'mulberry', иървени 'red (ones)', цървену вину 'red wine'. The same phenomenon is typical for the Sachanli dialect - one of the dialects that played a part in the formation of the Daretz dialect, since in the former, there are examples like цървѐн 'red' (masculine singular), цървенушка 'a kind of a mushroom' (literally - 'a red mushroom'), $u^{3}$ рен 'black' (masculine singular), църнѝца 'mulberry' (10).

The change $\boldsymbol{u} \rightarrow \boldsymbol{u}:$ учѐл 'who has gone' (masculine singular), учло 'who has gone (neuter singular)'.

The change $\boldsymbol{x} \rightarrow \boldsymbol{\phi} / \boldsymbol{s}$ : сра̀ $\phi$ 'fear', m'àфнни 'their', б'à $\phi$ 'I was', вид'à $\phi$ 'I saw', ca c'àmuфa 'they thought of something', слушава 'they listened'.

The change $\boldsymbol{\mu} \rightarrow \boldsymbol{x}$ : There are cases in which there is $ж$ instead of $\mu$ : ма̀нжа 'a meal', ма̀нжи 'meals', межѐ 'working-bee', жа̀мвету 'the windows', but: бойаийскет' ка̀мен' 'the dyer's stone', ча̀буцик 'immediately'.

\section{H. Development of consonantal groups Development of $* t j$, *dj}

The development of the first consonantal group, in general, is typical for the Bulgarian language: * $t j \rightarrow$ um: $H^{\prime}$ 'àmmy 'some(thing)', d'amumue 'a big child', ìmme '(he) wants', ùmетехме 'we wanted', ùmm'axa 'they wanted', nycpèumam 'they meet', umỳ 'what', but there are exceptions, too, containing the hard consonant $m$ : ucnàpmъm 'they send', cmỳ 'what', c'àmame ca 'we think of something'.
The situation with the second consonantal group is more specific: $* d j \rightarrow \partial$ (after hardened consonants)/uк: дуxỳda '(he) comes', dyxàdaxa 'they were coming', наху̀даме 'we find', изва̀даме '(he) was taking out', в 'а̀mки 'eyebrows'.

Development of élê and other similar groups Here, one can see diverse variants: $n^{3} p c$ 'finger', $в^{3}$ рзуват 'they tie', $n^{3}$ рвет 'the first (one)', ча̀рвy 'a gut', but: $m p^{3}{ }^{3}$ 'auction', вратѝ '(he) turns', са въртѝ '(he) turns himself' and ca paзварmù '(he) begins to turn', държимм 'we hold' and дарж ${ }^{3} m$ 'they hold', са $n^{3}$ лнеха 'they became full'; длѐzи 'long' (plural).

The change $u m \rightarrow c m: c m y ̀$ 'what'.

\section{Elision of consonants}

Elision of $m$ and $\partial$ from the consonantal groups cmp, здр: оेрy 'sharp' (neuter singular); зра̀ва 'in good health' (feminine singular), узрав'а̀ват 'they recover from an illness'.

Elision of consonants in other cases: $\partial^{3} p y$ 'a tree', ол 'вету 'the oxen', ода 'water', болес 'an illness', шѐс 'six', $\phi^{3}$ рлет' 'they throw', л'йй 'a spoon', зѐ '(he) took', зѐли 'these who have taken', дòprm 'the yard'.

\section{J. Softness of consonants}

In the dialect under research, this phenomenon is very common outside the standard uses: Вел'дѐн' 'Easter', бйл'ки 'herbs', болл'ка 'pain', ол'вету 'the oxen', ко̀л'ве 'stakes', миса̀л' 'a towel', темѐлет' 'the basement', Васйл' 'a personal name', о̀ген' 'fire', огенет' 'the fire', жйвет' огген' 'the live fire', коेн 'horse', коेнет' 'the horse', пара̀т'ка 'етрty', запа̀л'ваме 'we set fire', $n^{3} m$ ' '(one) time. In some cases, Mihaylova has not designated the softness of consonants by the letter $b(=$ ') but due to the transition ' $a$ $\rightarrow e$, one can conclude that, in those cases, the consonant before $e$ is soft, too: пуд миса̀ле 'under the towel' (in singular - миса̀л' 'a towel'), ym Гỳcnyde 'from God', денѐm 'the day', пепелет' 'the ash'. In госке 'guests', there is even a change $m^{\prime} \rightarrow \kappa$.

\section{CONCLUSIONS}

The phonetics of the Daretz dialect shows mainly the phenomena typical for the Rup dialects. That is why, on the phonetic level, it is more difficult to differentiate between the influence of the three main components that have formed it - Northern Thracian, Southern Thracian, and Rhodopean (the latter can contain not only elements from the Central 
Rhodopean dialect). This will be done more precisely when I have analyzed the morphological features of the dialect.

\section{REFERENCES}

1. Илиев, Ив. Г. (2006). Постижения и задачи на източнородопската българска диалектология. In: Илиев, Ив. Езиковедски опити. Пигмалион, Пловдив.

2. Мичев, Н. (2005). Речник на имената и статута на населените места в България. 1878-2004 г. Петьр Берон, София.

3. Михайлова, М. (1996). Село Дарец, Крумовградско. In: М. Михайлова. Етнографски проучвания на Идточните Родопи. Кърджали.

4. Михайлова - Op. cit.

5. Митринов, Г. (2007). Въпросително местоимение кина - употреба и разпространение. In: Филологически $и$ методически изследвания. Доклади от международна научна конференция, посветена на 100-годишнината от рождението на дои.. Стайко Кабасанов. Смолян - Люблин.

6. Митринов - Op. cit.

7. Илиев-Op. cit.

8. Митринов - Op. cit.

9. Тончева, Х., Илиев, Ив. Г. (2011). Към описанието на говора в село Припек, Джебелско. In: Традиции $и$ приемственост. 50 години полувисше и висше образование в Източните Родопи. II. Езикознание и педагогика. Фабер, Велико Търново (in the article, the stressed $b$ is shown as $i$, due to editor's negligence).

10.Бояджиев, Т. (1971). Речник на говора на c. Съчанли, Гюмюрджинско. In: Българска диалектология. Проучвания $u$ материали. Издателство на БАН. София, 6, 1971. 